\title{
Rural Development in a Cross-border Context Case Study: Romania-R. Moldova
}

\author{
Balasan Daniela Lavinia \\ lavinia.balasan@ugal.ro \\ Florin - Marian Buhociu \\ florin.buhociu@,ugal.ro \\ Dunărea de Jos University of Galați, Romania \\ "Education is the most powerful weapon you can use to change the world." \\ Nelson Mandela
}

\begin{abstract}
The impact of agriculture nowadays is increasingly important. Today, modern agriculture no longer has the role of creating food products only. Most of the time Rural is seen as a development promoter socio-sustainable economic growth due to the vision of continuous development of rural areas. This paper treats cross-border cooperation with the challenges and opportunities existing at this level. The efficiency of cross-border cooperation is based, for the most part, on the coordination of all pillars involved in the process. Thus, the failure of one of the levels leads to the reduction of efficiency. The purpose of this work is to analyse the impact of the University "Dunarea de Jos" on the Cahul Rayon within the Republic of Moldova. This paper seeks to point out the elements on which the potential for rural and agricultural development depends. Nowadays, rural development persists in a crisis zone, and the lack of a realistic vision of the future of both the Romanian village and the village beyond the Prut, leading to a Multi-functional rural development is increasingly present.
\end{abstract}

Keywords: rural, cross-border, Regional Development, education, socio-economic, cooperation.

\section{Introduction}

The promotion of rigorous substantiated policies based on prior studies and analyses means a useful element in delivering quality conclusions and having a positive impact on people's lives.

This work consists of two parts, namely:

- In the first part, the main notions referring to cross-border cooperation are reported and studied. The Collaboration links in the border area must open and dilute the barriers between populations, institutions and states, more specifically, to bring them closer, not to distance them. It Should not be forgotten that Romania supports the accession of Republic of Moldova to the European Union in the near future.

- In the second part we have the debate of the challenges and opportunities of cross-border cooperation. The main factor contributing to the efficiency of this cooperation is the expansion of the educational area, and more precisely the fact that the "Dunprea de Jos" University of Galati created an extension in the Republic of Moldova, and more specifically in Cahu under the name of the Transfrontalier Faculty of Humanities, Economics and Engineering. The Euroregion "Dunărea de Jos" created on the basis of the "Treaty on good neighborly relations and cooperation between Romania, the Republic of Moldova and Ukraine, the Trilateral Collaboration Protocol between the Governments of Romania, the Republic of Moldova and Ukraine" the cross-border and multicultural faculties of Cahul . This treaty was signed at Izmail on July 4, 1997.

The Republic of Moldova is a country where the rural areas prevails. Although most inhabitants live in rural areas, it suffers from a low socio-economic development. The Accession of the Republic of Moldova to the common European market calls for it to impose new 
strategies for the development and restructuring of the agricultural area and to combat negative effects.

\section{The role of cross-border cooperation}

About the rural environment we can say that it is a natural environment, which encompasses human activities, not being aggressive and not leading to its degradation. Often, the migration phenomenon was visible from the Uptown to the center. Most conflicts were encountered in rich border regions. "The people of the border regions, who have been affected in the highest degree from the aftermath of historical conflicts, have gained mutual fears and animosities in time. The conditions that gave rise to these relationships have damaged the availability of cooperation and establishing contact. ${ }^{11}$

Following the European construction process, more specifically the integration of European states into the Community structures, we see a change of the perception regarding the borders of the national states. These states have entered into an opening process in the European Union area. The enlargement of the European Union and the eastern area has resulted in a change in vision, extending the horizon of ideas for future development.

Cross-border collaboration links lead to changing and reducing barriers between populations, communities, institutions, organisations or countries.

We can define cross-border cooperation as a report that involves direct collaboration between neighboring regions, encountered along a border. This collaboration involves absolutely all areas, and ensures harmonious development, decreasing the degree of different development between regions. "The basic principle of cross-border cooperation is the realisation of contractual spaces in the frontier areas in order to enable the finding of common solutions to similar problems, State entities not ignoring, towards their peripheral communities, Particularity and specificity of the neighborhood problems they face. ${ }^{2}$

The main objectives of the cross-border cooperation process are:

"- promoting cooperation between areas, communities and authorities on both sides of the border, in developing common issues, through the design and implementation of cross-border strategies and projects to contribute to the development of those communities in terms of increasing living standards and economic development;

- promoting good neighborliness, social stability and economic progress in border regions, by financing projects with visible benefits for communities in these regions;

- Supporting the decentralization of accountability by promoting initiatives undertaken within the framework of local strategies. "3

\section{Cross-border cooperation between Romania and the Republic of Moldova}

As a member of the European Union, Romania is obliged to develop both bilateral ties with neighboring countries and to implement an European Union neighborhood policy towards the Republic of Moldova.

An operational program of financing for regional development in the field of crossborder cooperation was launched between 2007-2013 years. The program was launched with a total budget of 138,122,639 euros for the entire period.

\footnotetext{
${ }^{1}$ Trans-border cooperation,

http://zbw.eu/econisarchiv/xmlui/bitstream/handle/11159/127/St\%202_Cooperarea\%20transfrontaliera_final_0.pdf?s equence $=1$ \&isAllowed $=y$, accessed on 16.06 .2019

2 Clarles Ricq, cross-border cooperation Manual for the use of local and regional collectibles in Europe, THIRD Edition,

Bucharest, 2000, p. 10.

${ }^{3}$ Law No. 315 of 28 June 2014 updated on regional development in Romania, Chapter 1, article 3.
} 
The No. 1. Joint Operational Program Romania - Republic of Moldova in the period 2007-2013. Financial plan (EURO)

\begin{tabular}{|c|c|c|c|c|c|}
\hline & EU funds & $\begin{array}{lr}\text { Percentage } & \text { of } \\
\text { total } & \mathrm{EU} \\
\text { funding } & \end{array}$ & Co- financing & $\begin{array}{l}\text { Percentage of } \\
\text { co-financing }\end{array}$ & Total funding \\
\hline Priority 1 & 56.668 .623 & $45 \%$ & 5.666 .862 & $10 \%$ & 62.335 .485 \\
\hline Priority 2 & 44.976 .39 & $35 \%$ & 4.497 .639 & $10 \%$ & 49.474 .030 \\
\hline Priority 3 & 12.401 .246 & $10 \%$ & 1.240 .125 & 105 & 13.641 .371 \\
\hline Priority 4 & 12.671 .807 & $10 \%$ & $\mathrm{n} / \mathrm{a}$ & $\mathrm{n} / \mathrm{a}$ & 12.671 .807 \\
\hline Total & 126.718 .067 & $100 \%$ & 11.408 .626 & - & 138.122 .639 \\
\hline
\end{tabular}

Source: Data processed under the Joint Operational Program Romania-Republic of Moldova period 2007-2013, FUNDED BY the ENPI

The program extends to Romania on the Moldovan side, and in the Republic of Moldova, it stretches throughout the country. It had a real success, recording in the first year approximately 422 applications, only few of them being recorded in the Republic of Moldova and the most being in our country. The most important project was the improvement of the relations between our country and the Republic of Moldova when it comes to food and petroleum products. This project also took into account the improvement and modernization of border crossings points.

Another important project was represented by the prevention of floods in the Prut and Siret river basins. The purpose of this project was to protect the districts near the two rivers by performing modernisation works.

Sustainable cross-border cooperation would lead to more jobs, increased exports to the European Union, improved police services, and accelerated rural development. In the Republic of Moldova agriculture is a very important sector, but it is in decline. Over the past decade, the contribution of agriculture to gross domestic product has been decreasing on average by $10 \%$ in all Eastern European countries. In the following figure we observe the gap between the various eastern areas.

Figure No. 1. Contribution of agriculture to GDP2003-2016 in the Republic of Moldova

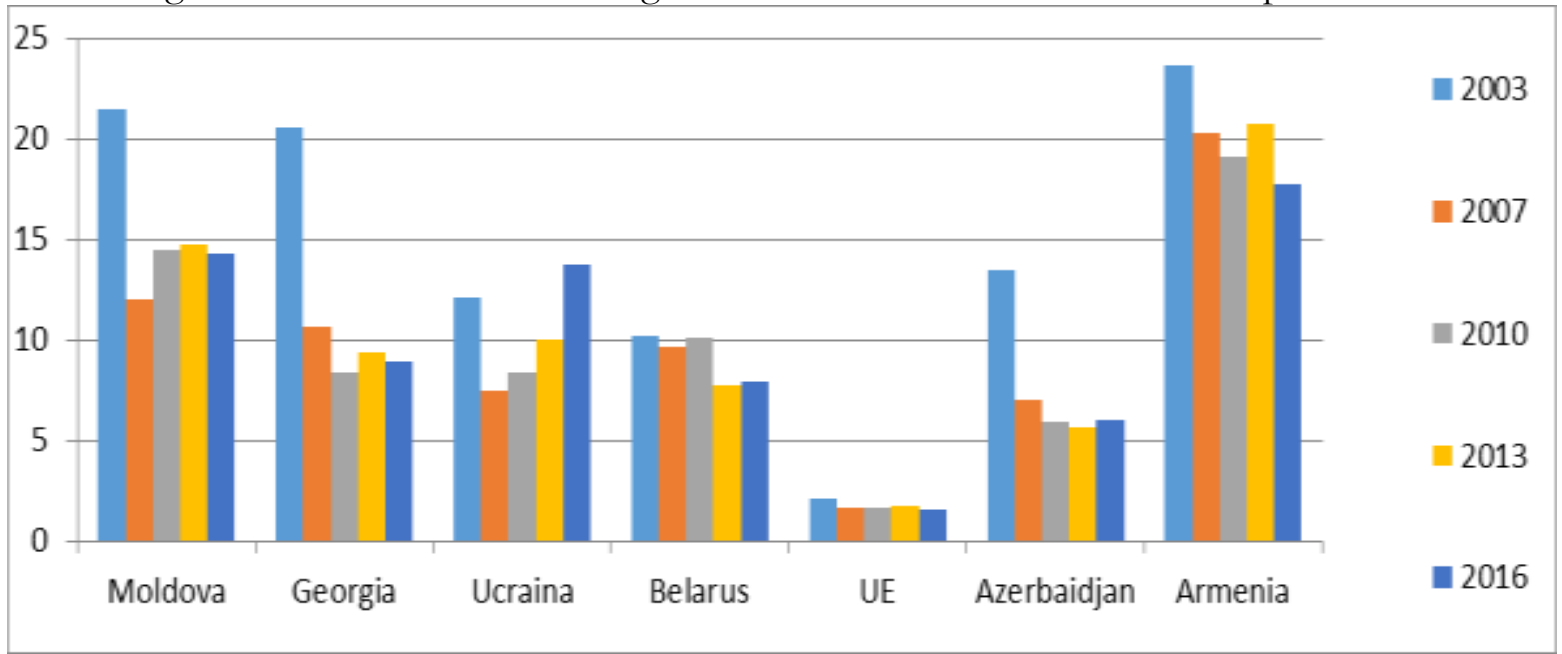

Source: The official website of the World Bank

The main cause is agriculture's dependence on climate conditions, but also the economic crises that have led to prices ikes, leading to major difficulties.

The Republic of Moldova can enjoy a soil characterized by predominant fields with fertile and productive chernozems. The development of agricultural land and the significant reduction of forest areas have led to a negative impact on the hydrological regime. 
SWOT Analysis

Next, I will present an analysis showing the strengths and weaknesses of the agricultural and rural sectors of the Republic of Moldova.

Strengths:

- Agriculture is of major importance in the national economy;

- The Republic of Moldova can enjoy a very good geographic position;

- The Internet network is highly developed throughout the last period;

- The Republic of Moldova is a country with tradition in wine, vegetables and fruits.

Opportunities:

- Development of production in the internal and external market;

- Increasing research services;

- Use of abandoned land;
Weaknesses:

- The agricultural sector did not have a strong promotion and funding;

Animal production is not effective;

- Soil quality suffers erosions;

- Leaving the rural area by the inhabitants and moving them to cities for better employment or more developed living conditions.

Threats:

- Frequent climate change;

- The occurrence of diseases in plants or animals.

\section{Cross-border cooperation in the field of education}

Due to the decline of all sectors in the economy, education in the Republic of Moldova has been affected. The education allowances instead of an increase they get increasingly lower. Decreased birth rates and mass migration of the population to more developed countries leads to a reduction in the number of students.

"Moldova's agricultural education system is outdated and affected by a discrepancy between skills and knowledge taught and demanded on the labor market . ${ }^{4}$

These days there is an attempt to change the quality and performance of higher education. This change is not desired by everyone. "In the attitude towards the reform of higher education, two extreme trends are shaping, namely:

- The state wants centralized management where important decisions are taken at a central level, and universities have the role of applying them;

- Universities desire a decentralized management based on unlimited academic autonomy; ${ }^{5}$

After 2013, it was decided to implement new education plans for educational institutions. These plans aim at preparing students for baccalaureate and continuity of studies.

Currently, the two ministries, namely the Ministry of Education and Research in our country and the Ministry of Education of the Republic of Moldova, are working together on a two-way development aimed at capitalizing on education and training.

In 1999, the Faculty of Philology and History and the faculty of Sciences began their activities. After 2000, other fields such as mathematics, sciences engineering and local public administration appeared.

The academic year 2004-2005 recorded a number of 459 students from Romania, Moldova and Ukraine. They had the status of scholars of the Romanian State.

${ }^{4}$ http://documents.worldbank.org/curated/en/602591468196193029/pdf/105724-WP-P151472-PUBLIC-ROMANIAN- 
Table No. 2. Studentsof the cross border of Cahul Rayon

\begin{tabular}{|c|c|c|c|c|c|c|}
\hline & Annulment & Year II & Year III & Year IV & Year V & Total \\
\hline $\begin{array}{l}\text { Student } \\
\text { No. }\end{array}$ & 104 & 101 & 99 & 122 & 33 & 459 \\
\hline \multicolumn{7}{|c|}{ Of which: } \\
\hline And & 18 & 24 & 23 & 22 & - & 87 \\
\hline I & 17 & 15 & 18 & 20 & - & 70 \\
\hline IE & 17 & 20 & 21 & 16 & 16 & 90 \\
\hline IPA & 17 & 18 & 18 & 19 & 17 & 89 \\
\hline AP & 18 & - & - & 20 & - & 38 \\
\hline $\mathrm{MF}$ & 17 & 24 & 19 & 25 & - & 85 \\
\hline
\end{tabular}

Source: Date own processed from the official site of the faculty http:/ / www.transuei.ugal.ro/ despre.htm accessed on 21.06.2019

Following the decision of the Government with the number 676 of the year 2007, the name of the faculty changed in the Cross-Border Faculty of Humanities, Economic and Engineering sciences. The "Dunarea de Jos" University of Galați provides the faculty with a teaching staff consisting of approximately 200 academic staff, of which 45 university professors, 40 engineers and 50 lecturers. They go to Cahul daily to support the courses. The small distance between Cahul and Galați makes it possible for them to be optimally displaced for the proper functioning of the faculties.

The Faculty of Cahul district operates and relies on the following principles:

"-the preservation and strengthening of the academic spirit in the faculty;

- Promoting and respecting scientific, cultural and moral values, regardless of age or position in the university hierarchy;

- To make it possible for students to become partners;

- Promoting a spirit of collegiality, fairness, transparency and democratic settlement of all issues;

- Total transparency in decision-making;

- Full compliance with the legislation in force. ${ }^{16}$

\section{Conclusions and suggestions}

Improving cooperation between local parties and the existence of a visible access to funds would lead in a sustainable development of local communities.

One of the most important factors is political instability. This slows down good progress and the welding of cross-border cooperation between Romania and the two neighboring countries, Ukraine and the Republic of Moldova. This factor leads to the postponement of judgments concerning the implementation of the projects with European financing or funding from the State budget.

If we report to the weaknesses highlighted in the SWOT analysis, actions can be proposed to reduce the effect of deficiency and contribute to the fruition of opportunities. I consider that an attempt to develop the rural environment involves first and foremost solving the persisting problems. Non-exploration and non-stimulation of agricultural potential is a key factor that prevents sustainable development.

The process of rural development can be stimulated by supporting the economy, thus driving the financial process in the agricultural sector, but also by supporting modern equipment. Professional training of agricultural workers and the existence of advisory services would lead to efficient and innovative management.

The modernization of the transport infrastructure, the railways and the improvement of the water transport lead to the support and creation of new connections with the environment.

${ }^{6}$ Official website of the faculty http://www.transuei.ugal.ro/program.htm Retrieved 21 June 2019. 
If we think about educational infrastructure, the rural environment needs great investment. Programs aiming at the characteristics of education in the degraded environment are needed for sustainable development. The educational field can mean one of the most significant areas to be changed from the last period. Both Romania and the Republic of Moldova face major challenges regarding the quality of the education system. In both countries, most rural schools are in a precarious situation.

The "Dunarea de Jos" University of Galaţi created an extension in Cahul called the CrossBorder Faculty of Humanities, Economic and engineering sciences comprising both bachelor's degree and Masters. The management process works entirely on the basis of the strategic plan of the University of Galați. The development of cross-border relocations between Romania and Moldova is sought. The University leadership wants coordinate and refine the curricula, and also to develop of socio-economic relationships.

\section{References}

1. Bubociu F.M., teritorial resources to support sustainable rural development in the European context, Europlus Publishing house, Galati, 2016

2. Clarles Ricq, cross-border cooperation Manual for the use of local and regional collectibles in Europe, THIRD Edition, Bucharest, 2000

3. Constantin DL., regional economics theories, models, policies, ASE Bucharest publishing house, 2010

4. Dona I., rural economy, Economic publishing house, Bucharest, 2007

5. Law No. 315 of 28 June 2014 updated on regional development in Romania, Chapter 1, article 3.

6. Manual of Cooperación Transfronteriza, European border Region Association (AEBR), Berlim, 2014

7. Strategy for cross-border cooperation IEPV 2007-2013

8. National strategy for Regional Development of the Republic of Moldova 2013-2015, October, 2015

9. Joint Operational Programme Romania-Ukraine-Republca Moldova 2007-2013

10. http://zbw.eu/econisarchiv/xmlui/bitstream/ handle/11159/127/St\%202_Cooperarea\%20transfrontali era_final_0.pdf?sequence $=1$ \&is_Allowed $=y$

11. bttps:// utm.md/ edu/legal/strategia_rm.pdf

12. bttp:// wnw.transuei.ugal.ro/program.htm 